\title{
THE MANAGEMENT OF KYAI DEVELOPMENT THROUGH POLITE LANGUAGES TO FORM AKHLAKUL KARIMAH SANTRI IN THE PESANTREN
}

\author{
Arum Maslachah'), Sofyan Sauri $\left.{ }^{2}\right)$ Helmawati $^{3)}$ \\ 1,2,3 Universitas Islam Nusantara Bandung, Indonesia \\ email: arummaslachah@gmail.com \\ email: sofyan_56@yahoo.co.id \\ email: helmawati.dr@gmail.com
}

\begin{abstract}
Abstrak
Penelitian ini bertujuan untuk mendeskeripsikan bagaimana manajemen pembinaan kyai melalui kesantunan bahasa dalam meningkatkan akblakul karimah santri di Pondok Pesantren Miftabul Khoir Kota Bandung. Penelitian ini menggunakan pendekatan kualitatif. Sedangkan metode yang digunakan adalab Studi Kasus (Case study) yang merupakan suatu proses pengumpulan data dan informasi secara mendalam, mendetail, intensif, holistik, dan sistematis tentang orang, kejadian, latar sosial, atau kelompok dengan menggunakan berbagai metode dan teknik serta banyak sumber informasi untuk memahami secara efektif bagaimana orang, kejadian, latar alamiah (social setting) itu beroperasi atau berfungsi sesuai dengan konteksnya. Hasil penelitian menunjuk.kan bahwa manajemen pembinaan kyai melalui kesantunan bahasa dalam meningkatkan akhlakul karimah santri dilaksanakan melalui metode keteladanan, metode latihan dan pembiasaan, dan metode pembelajaran. Dimana melalui metode-metode tersebut santri terbiasa mengucapkan salam, bertutur kata sopan, santun, lemah lembut, rendah diri, dan tidak berkata kasar.
\end{abstract}

Kata Kunci: Manajemen, Kesantunan Bahasa, Akhlakul Karimah

\begin{abstract}
This study aims to describe how the management of kyai coaching through politeness in improving the morals of the santri at Miftahul Khoir Islamic Boarding School, Bandung City. This research uses a qualitative approach. While the method used is a case study (Case study) which is a process of collecting data and information in depth, detail, intensive, holistic, and systematic about people, events, social backgrounds, or groups using various methods and techniques as well as many sources of information. to understand effectively how people, events, natural settings (social settings) operate or function in accordance with the context. The results showed that the management of kyai guidance through politeness in improving the morals of the santri was carried out through exemplary methods, training and habituation methods, and learning methods. Where through these methods the students are accustomed to saying greetings, speaking polite, polite, gentle, low self-esteem, and not speaking harshly.
\end{abstract}

Keywords: Management, Polite Language, Akhlakul Karimah

\section{INTRODUCTION}

Everyone has a way to communicate with others in everyday life. The function and position of language is very important in communicating, because language is a means of communication in interacting. The language used by each individual is different and characterizes each human being. The presence of language is a person's personal point of view, both in terms of a person's character, character or personality, it can be seen from the selection of the language he 
uses. Every conversation has a purpose that is not merely to exchange information, but can also show the existence of other humans in their environment. Speech that is carried out either directly or indirectly is influenced by certain elements or aspects. One of them is politeness and politeness. The use of language politeness allows social transactions to take place without embarrassing speakers and speakers (Khotimah, 2017).

However, politeness in language in society has recently decreased. Often heard words that offend people that come out of the mouths of those around us, especially teenagers. The problem today is that parents are confused about dealing with their children who often say harshly. Even today's teens or children often utter harsh words when calling their friends, when they are shocked, or when they are upset.

The cause is related to a person's low appreciation of language. Immodesty is also not only related to choice of words, but also to social customs. If we hang out in an environment that often says harsh and disrespectful words, then automatically / unconsciously we will follow. The time factor can also cause changes in the values of politeness, for example, ancient people maintained much more politeness when they interacted with language when they interacted with people today. Politeness is also related to the place, for example politeness at school or boarding school must be different from our politeness at home and terminal (Natashia, 2016).

Another factor that is very decisive in the preservation and heritage of this language culture is education. Children need to be nurtured and educated in polite language, because they are the next generation who will live in their day. If children are left with their language, it is not impossible that the polite language that already exists can be lost and then a generation that is arrogant, rude, and dry from ethical and religious values will be born.

Temporary observations show that the result of violent and arrogant language expressions among adolescents often leads to fights and fights between them. On the other hand, those who are accustomed to polite language are generally able to act as good members of society (Wijaya, 2017a).

Lakoff in (Gunarwan, 2006, 2002) argues that there are three rules that need to be obeyed so that our speech sounds polite to listeners, namely formality, hesitancy and equality or camaraderie. When explained the three rules above, formality means not being pushy or arrogant, indecisiveness means making it in such a way that the interlocutor can make a choice, and the three equality or solidarity means as if the speaker and the interlocutor are the same. According to Lakoff, a speech is said to be polite if it does 
not sound pushy, it gives choices to the interlocutor, and the interlocutor feels calm. The conclusion of the explanation above is that politeness is used in speech so that the narrative goes well (Shobirin \& Roziqin, 2019).

The use of the principle of politeness in communication needs to be carried out by speech actors in the hope that the meaning of the speech is well understood and does not hurt the feelings of speakers and interlocutors. According to (Rahardi \& Rahardi, 2005), language politeness can be seen through word selection (diction) to sentence arrangement, grammar, variety choices, and the use of tempo and intonation. One of the strategies for using politeness in communication can be done by respecting and respecting each other between the speaker and the interlocutor (Inderasari et al., 2019).

Abdurrahman Wahid as cited by (Rahardjo, 1999) states that pesantren are called subcultures because there are three elements that make up Islamic boarding schools, namely, first, the leadership patterns of independent Islamic boarding schools are not co-opted by the State, second, general reference books that are always used from various centuries, and third, the value system used is part of society at large (Muslimin \& Kartiko, 2020; Salis, 2020). The uniqueness of the Islamic boarding school can be seen from the use of a traditional leadership system, the social relations between kyai and santri are built on the basis of trust and respect for someone who has high religious knowledge. It is not true respect for humans, but rather to the height of knowledge that Allah SWT has given to a kyai (Hasbi \& Diani, 2020).

The managerial process of Islamic boarding schools will have an effect on improving the quality of the students as expected. Therefore, the system of improving the quality of students is a manifestation of the boarding school managerial system (Habibi \& Supriatno, 2020). Management can run well if its functions are going well. Management functions which include planning, organizing, actuating, controlling, will be the driving force in determining the managerial direction of the Islamic boarding school (Tambak et al., 2021).

Likewise at the Miftahul Khoir Islamic Boarding School in Bandung City, to achieve its goal of improving the quality of students, an effective and efficient management process is needed. The management of kyai coaching in Islamic boarding schools is very much needed in carrying out the wheels of the institution in order to be able to print and improve the quality of students that are beneficial to religion and the state. Based on the above background, this research is focused on the management of kyai guidance through 
politeness in improving the morals of the santri at the Miftahul Khoir Islamic Boarding School, Bandung City which is formulated in four aspects of management functions (planning, organizing, implementing, and supervising) at the Miftahul Islamic Boarding School Khoir City of Bandung.

\section{LITERATURE REVIEW}

\section{Management of Kyai Development}

Management, according to George Terry, is an act of someone who has the right to order other people to do something, while the responsibility remains in the hands of those who order planning, organizing (organization), moving (actuating) and controlling (controlling) known as POAC. Meanwhile, according to Harold Kontz and Cril O'Donnel management is an effort to achieve a certain goal through other people's activities including planning, organizing, placing, mobilizing and controlling. Likewise, the opinion of Sergiovanni, Burlingame, Coombs and Thurston which defines management as a "process of working with and through others to accomplish organizational goals efficiently", namely the work process with and through empowering others to achieve organizational goals efficiently (Dhuhani, 2018).

Regarding management functions, some have argued: planning, organizing and controlling; planning, organizing, actuating and controlling; planning, organizing, staffing, directing, representing and controlling; planning, organizing, coordinating and controlling; planning, organizing, assembling of resources, directing and controlling; planning, organizing, motivating and controlling; planning, organizing, leading and controlling; and planning, organizing, staffing, directing and controlling (Asifudin, 2016). With a variety of considerations, here the latter is chosen to be used.

The managerial process of Islamic boarding schools will have an effect on the results of improving the quality of the students as expected. Therefore, the system of improving the quality of students is a manifestation of the boarding school managerial system. Management can run well if its functions are going well. Management functions which include planning, organizing, actuating, controlling, will be the driving force in determining the managerial direction of the boarding school.

Pondok pesantren is an Islamic religious education institution that grows and is recognized by the surrounding community, with a boarding system in which students receive religious education through the recitation system or madrasah which is fully under the sovereignty and leadership of one or several Kyai people with distinctive 
characteristics. charismatic and independent in all things (Nurmela \& Rifa, 2016).

The existence of the Kyai as the leader of the pesantren, in terms of their duties and functions, can be seen as a unique phenomenon. It is said to be unique because the kyai as the leader of an Islamic educational institution is not only tasked with compiling a curriculum, making rules or regulations, designing an evaluation system, as well as carrying out the teaching and learning process related to the religious sciences in the institution he cares for, but also as a coach and educator people and become community leaders (Hasbi \& Diani, 2020).

Pesantren is indeed currently consolidating institutional organizations, particularly in the aspects of leadership and management (Ma`arif \& Kartiko, 2018; Supian et al., 2020). Traditionally, the leadership of the pesantren has been held by one or two kyai, who are usually the founders of the pesantren concerned. However, due to the diversification of education, the kyai's sole leadership was no longer sufficient. Many pesantren then develop institutional foundations which are basically collective leadership.

In a more practical way, Abdurrahman Wahid pointed out several selective projects that could be carried out by pesantren and supported by the government as an effort to dynamize the pesantren. Then, individually, each pesantren selects one of the predetermined projects. In general, this selective project work can be classified into several groups. First, the pesantren leadership coaching group which focuses on leadership patterns that are in accordance with the interests of the pesantren in the future. Second, the teaching quality coaching group in pesantren which includes projects including: preparation of a curriculum that is more relevant to the needs of the community, preparation of a teaching syllabus, periodic arrangement for teaching staff, and so on. Third, the group fostering patterns of relations between pesantren and other social institutions, including patterns of relationships with religious institutions outside of Islam, development and investigation institutions in various fields, and government agencies. Fourth, the skills development group for students, including both technical vocational education and character education, are able to bear the burden of skill ideas themselves well (Nurmadiansyah, 2016b).

\section{Politeness of Language}

Politeness in language is an important thing for every society to do when communicating. In communicating, these norms can be seen from verbal behavior and nonverbal behavior. Verbal behavior in an imperative function, for example, is seen in how speakers express orders, musts, or prohibitions on doing something to the 
speech partner. Nonverbal behavior can be seen from the form of mimics, gestures, attitudes or behaviors that support the expression of a person's personality (Ardhiarta, n.d.).

There are several linguists who argue about the politeness of language. Politeness in an interaction can be defined as a tool used to show awareness of other people's faces. Lakoff in Gunarwan (1994) argues that there are three rules that need to be obeyed so that our speech sounds polite to listeners, namely formality, hesitancy and equality or camaraderie. When explained the three rules above, formality means not being pushy or arrogant, indecisiveness means making it in such a way that the interlocutor can make a choice, and the three equality or solidarity means as if the speaker and the interlocutor are the same. According to Lakoff, a speech is said to be polite if it does not sound pushy, it gives choices to the interlocutor, and the interlocutor feels calm. The conclusion of the explanation above is that politeness is used in speech so that the narrative goes well (Shobirin \& Roziqin, 2019).

Politeness in language may be a new horizon in language, and until now it has not been studied in the linguistic constellation; except in studies pragmatics. Politeness in language, although it is called a new horizon, has already received attention by many linguists and pragmatists (Supratman, n.d.).

Of course, good language must follow the existing rules so that every speech spoken can produce polite language. Leech stated that someone is said to have the politeness of language if they can fulfill the principles of politeness (Wijaya, 2017b).

In interacting and communicating, politeness is an important aspect to be raised. Politeness and politeness are useful for creating good relationships and communication in social interaction between speakers and speakers. Both are meant to generate respect for oneself and others. So that the level of politeness and politeness will affect the values and perspectives of others towards him. In addition, people will further strengthen the relationship between the two of them (Khotimah, 2017).

The use of the principle of politeness in communication needs to be carried out by speech actors in the hope that the meaning of the speech is well understood and does not hurt the feelings of speakers and interlocutors. According to Rahardi (2005), language politeness can be seen through word selection (diction) to sentence arrangement, grammar, variety choices, and the use of tempo and intonation. One of the strategies for using politeness in communication can be done by respecting and respecting each other between the 
speaker and the interlocutor (Inderasari et al., 2019).

Lakoff as quoted by Gunarwan (1994) argues that there are three rules that need to be obeyed so that our speech sounds polite to listeners, namely formality, hesitancy and equality or camaraderie. When explained the three rules above, formality means not being pushy or arrogant, indecisiveness means making it in such a way that the interlocutor can make a choice, and the three equality or solidarity means as if the speaker and the interlocutor are the same. According to Lakoff, a speech is said to be polite if it does not sound pushy, it gives choices to the interlocutor, and the interlocutor feels calm (Shobirin \& Roziqin, 2019).

The conclusion of the explanation above is that politeness is used in speech so that the speech goes well in accordance with existing rules.

\section{METHOD}

This research uses a qualitative approach. While the research method used is a case study, which is a process of collecting data and information in depth, detail, intensively, holistically, and systematically about people, events, social backgrounds, or groups using various methods and techniques as well as many sources. information to understand effectively how people, events, natural settings (social settings) operate or function in accordance with the context (Ita Herlitasari, Mustolah Maufur, 2020).

The case study used in this research is an observational case study. Where the aim is to describe and obtain detailed data regarding the management of kyai coaching through language politeness in improving the morals of the santri at the Miftahul Khoir Islamic Boarding School, Bandung City.

This research was conducted in July, from the time the author wrote the proposal until November. This research was conducted at the Miftahul Khoir Islamic Boarding School, Bandung City.

The subjects of this study were the Board of Directors of the Islamic Boarding School, the parenting section, and the students.

The procedures of this research are: First, pre-field, that is, the researcher makes observations to determine the initial state as the material poured in the background of the problem. Before entering the field, researchers first asked for research permission from the Faculty of Management of Islamic Education, Universitas Islam Nusantara Bandung. Then the researcher submitted a research letter and made observations in the field to find out more about the management of kyai development through language politeness in improving the morals of the santri at Miftahul Khoir Islamic Boarding School, Bandung. Second, 
exploration so that the data collected is in accordance with the formulation of the problem and the research objectives, then the exploration stage is carried out or the stage of research in the field is carried out. Third, Member check, this stage is carried out by reviewing the research report manuscript by several parties involved, including supervisors, informants and participants in this research. This stage is carried out by rearranging the data that has been obtained through interviews, observation and documentation studies, then reported.

\section{Data Collection Technique}

Data collection techniques used in this qualitative research are observation, interviews, and documentation. The data collection methods in their use can complement and support each other during the data processing.

Observations in this study use the type of participant observation, namely observers regularly participate and are involved in the activities being observed, the activities in question are activities coordinated by the board of the Islamic boarding school.

The type of interview used in this research is a structured interview type in which the researcher has prepared a research instrument in the form of written questions whose alternative answers have also been prepared. Researchers conducted interviews with the Board of Directors of the Islamic Boarding School, the parenting and asatidz section, and conducted more indepth interviews with the students.

The documentation used in this study was taken from Islamic boarding schools data, such as the Islamic Boarding School Profile, Pesantren Vision and Mission, Number of Students, Islamic Boarding School Curriculum, Organizational Structure and Education Personnel, Student Organizational Structure, Work Programs, Students Daily Data, and Activities Photos. Data analysis technique The data analysis technique used in this study was based on the stages according to Miles and Huberman, namely the stage of data reduction, data presentation, and drawing conclusions or verification. Meanwhile, checking the validity of the data through a credibility test using the Triangulation technique. Triangulation is a technique in collecting data to obtain findings and interpret (interpret or explain) data that is more accurate and credible. According to (Sugiyono, 2015) that triangulation is defined as checking data from various sources in various ways, and at various times.

\section{RESULTS AND DISCUSSION}

At this stage the researcher will present the data from the observations and interviews the researcher has done before. The object of this research is kyai, asatidz, and santri, which is about the management 
of kyai development through language politeness in improving the morals of the santri.

Management of Islamic Boarding School Education is essentially a process of structuring and managing Islamic Boarding School education institutions that involve human and non-human resources in moving to achieve the objectives of Pesantren Education effectively and efficientl (Nurmadiansyah, 2016a).

Based on the results of interviews and observations, the leadership of the kyai at the Miftahul Khoir Islamic Boarding School is still natural. Neither the development of the pesantren nor the process of coaching prospective leaders have not had a regular and permanent form. In some ways, this pattern does produce continuity of good leadership, but not a few who experience shortcomings.

From the program used as applied management, researchers analyzed that the Miftahul Khoir Islamic Boarding School in Bandung has applied management functions, namely planning, actuating, and evaluating to determine a goal to be achieved together.

\section{Planning}

Planning is an activity to set goals to be achieved along with ways to achieve these goals. The planning function is identical to the formulation of strategies, standards, and direction and goals in achieving organizational goals .

In every plan there are always three activities, namely (1) formulation of objectives to be achieved (2) selection of programs to achieve that goal identification and mobilization of resources whose numbers are always limited.

The results of the interview showed that before making the program, of course, all administrators had to first compile a work plan in an effort to foster the morals of students at the Miftahul Khoir Islamic Boarding School in Bandung City in the form of short-term, medium-term and longterm programs. However, the work plan must be with the approval of the highest leadership, namely the Pondok Caretaker, so that work programs can be formed such as mandatory activities that must be followed by all students such as compulsory prayer in congregation, reciting the Koran, reciting books, ta'limul khitobah.

Planning activities at the Miftahul Khoir Islamic Boarding School in Bandung City in order to foster students towards language politeness in shaping morals in general are contained in the daily activities of students. The planning of these activities includes compulsory prayer in congregation, reciting the Qur'an, and in learning activities.

\section{Actuating}

Of the entire series of management processes, implementation is the most 
important management function. The implementation function places more emphasis on activities that are directly related to the people in the organization.

The results of an interview with one of the ustadz which was strengthened by the results of observations in the field showed that in its implementation efforts to integrate educational values, especially through language politeness in shaping the morals of the santri, Miftahul Khoir Islamic Boarding School has at least seven methods applied in shaping santri behavior, namely:

\section{Exemplary Methods}

Psychologically, humans really need an example to develop their traits and petitions. Behavioral education through modeling is education by providing concrete examples for the students. In pesantren, exemplary giving is emphasized. Kyai and ustadz must always provide good uswah for the students, in ritual services, daily life and others, because their value is determined by the actualization of what is conveyed. The more consistently a Kyai or ustadz guard his behavior, the more his teachings will be heard

\section{Exercise and Habitual Methods}

Educating behavior with practice and habituation is to educate by providing exercises against the norms and then familiarizing the Santri to do it. In education in Islamic boarding schools, this method will usually be applied to amaliyah worship, such as congregational prayer, politeness to Kyai and ustadz. Intercourse with fellow students and the like. In such a way, it is not uncommon in pesantren to find, how santri are very respectful of ustadz and their seniors and are so polite to their younger siblings, they are indeed trained and cultivated to act in this way. This practice and habituation will eventually become morals that are embedded in oneself and become inseparable.

\section{Educating Through Ibrah (Taking Lessons)}

The pedagogical goal of ibrah is to bring people to the satisfaction of thinking about religious matters that can move, educate or increase religious feelings. The taking of ibrah can be done through exemplary stories, natural phenomena or events that have occurred, both in the past and now.

\section{Educating Through Maui'dah (Advice)}

Educating through Mami'dah means advice, Rasyid Ridha defines Maui'dah as follows. "Maui'dab" is a warning admonition of goodness and truth in what way can touch and touch the heart and raise it to practice.

\section{Educating Through Discipline}

In education, discipline is known as a way to maintain the continuity of educational activities. This method is synonymous with punishment or sanctions. The aim is to raise the awareness of the students that what they are doing is not 
right, so that they do not repeat it again. In pesantren, this punishment is known as takzir. Takzir is a punishment imposed on students who violate. The heaviest punishment is being expelled from the pesantren. this punishment was given to students who had repeatedly committed offenses, as if they could not be repaired. Also given to students who violate with serious violations that tarnish the good name of the pesantren.

\section{Educate Through Targhib Wat Tahzib}

This method consists of two methods simultaneously which are related to each other; targhib and tabzib. The Targhib method is a promise accompanied by persuasion so that someone likes to do good and stay away from evil. Tahzib is a threat to create a fear of doing wrong.

\section{Educate Through Independence}

Behavioral independence is the ability of a santri to take and carry out every decision freely. The process of making and implementing santri decisions that usually take place in pesantren can be categorized into two, namely decisions that are important-monumental in nature and decisions that are daily in nature. In this paper, the decisions in question are decisions that are of a daily routine in nature.

The implementation of Kyai coaching in shaping the morals of the santri is integrated through several methods. Through these methods students are expected to be accustomed to practicing educational values such as greeting each other, saying greetings, speaking polite, polite words.

\section{Evaluation}

Evaluation of the coaching program in forming the morals of santri at the Miftahul Khoir Islamic Boarding School in Bandung is carried out by monitoring activities that have been, are currently and will be carried out to find out the results so that it can be assessed whether the activities aimed at fostering santri who end in career are going well according to the plan. or not.

In this case, the board of the Miftahul Khoir Islamic Boarding School in Bandung City has coordinated with a team of teachers and cottage caregivers to supervise and control whether the activity program is carried out according to plan or not. Because what is no less important in the supervision process in the implementation of activities at the Pondok is the communication so that you can find out the conditions and progress of the activities being carried out.

Evaluation of the guidance program in shaping the morals of santri at the Miftahul Khoir Islamic Boarding School, Bandung City in general, is carried out directly and indirectly in daily, monthly, and annual evacuations.

Daily evaluation is an evaluation that is directly followed up on matters in the 
form of problems, this evaluation is carried out by Kyai, a team of teachers, and also high-class santri who are given authority by the pesantren leader (Kyai). Monthly evaluation is an evaluation that has been scheduled continuously. This monthly evaluation discusses pesantren problems. Whether it's about santri in particular, generally regarding pesantren problems that have been collected and then held in the form of a meeting

Likewise, the annual evaluation is scheduled continuously. The pesantren leadership (Kyai) has a dominant role in evaluating the problems of the pesantren, including the students, the guardians of the students, the team of teachers, and the assistant to the leadership of the boarding school.

All of these things were done in an effort to develop the potential, educational values, and of course the morals of the santri miftahul Khoir. Therefore, this educational institution automatically has outputs that are useful for the country, nation and religion.

\section{Supporting and Inhibiting Factors}

As the result of an interview with one of the clerics that the guidance of the kyai in improving the morals of the santri through politeness at the Miftahul Khoir Islamic Boarding School, Bandung, are as follows:

\section{Wise Kyai}

Kyai is the most essential essential element in Islamic boarding schools. It is only natural that the growth of a pesantren depends solely on the personal abilities of the pesantren leadership itself (Kyai). Kyai is very influential on the progress of a boarding school The wise caretakers are very supportive in shaping the personality of the students themselves and become examples/public figures for the pesantren environment and the surrounding community.

\section{Competent Teacher}

The second factor is the ustadz and ustadzah (teaching teachers) who are competent as supporting factors in pesantren education, which help develop the personality of the students. The teaching teacher also provides direction and guidance to all students to comply with the applicable regulations at the Miftahul Khoir Islamic Boarding School in Bandung City. This is done to minimize violations by students.

\section{Firm Management}

Managers who have a firm attitude are one of the factors supporting the coaching system at the Miftahul Khoir Islamic Boarding School in Bandung City in shaping the personality of the students. The caretaker is the right hand of the nanny. So that all activities that take place at the boarding school are regulated by the 
management with the approval of the caregiver.

\section{Consistent Regulation}

Consistent regulations are one of the factors that influence the operation of the boarding school education system in shaping the personality of the students. With the existence of regulations/laws in force at the Miftahul Khoir Islamic Boarding School in Bandung, all students are required to obey these applicable regulations. All students who violate the rules will get $t a^{\prime}$ ziran (punishment) from the caregivers and administrators. The hope of the caregivers and administrators with the existing regulations, all students can be orderly, disciplined and responsible for all their actions.

\section{Comfortable Cottage Environment}

A safe and comfortable cottage environment is one of the factors that influence the boarding school guidance system in shaping the morals of the santri at the Miftahul Khoir Islamic Boarding School, Bandung City. The boarding school environment starts from caregivers who always support activities at the Islamic Boarding School, the Asatidz Council, administrators, peers, and others.

\section{Adequate Infrastructure}

To support all activities in this boarding school, complete infrastructure is one of the supporting factors as well. Adequate room space, mosque, spacious hall, bathroom, ablution place, comfortable classrooms, so as to make the students feel comfortable in the cottage and enthusiastic in participating in the teaching and learning process at the cottage.

Apart from those mentioned above, that which is a supporting factor for fostering kyai in improving the morals of santri through politeness is that the Miftahul Khoir Islamic Boarding School in Bandung City has teaching staff who are directly drawn from alumni who have developed their knowledge in various universities and Islamic boarding schools, of course, this can be used as a direct opportunity, namely to form santri who have good morals.

As for the factors inhibiting the development of the kyai in improving the morals of the santri through politeness, among others: the students' lack of awareness, the facilities and infrastructure that may have to be renewed and improved in terms of quality and quantity to support the development of potential, and the personality of the students, learning methods sometimes monotonous.

\section{CONCLUSION}

Based on the above discussion, that by looking at the current state and condition of Bandung City, each party needs to be careful and be aware of the bad and inappropriate associations of children and adolescents which will indirectly affect students and students. who have the status of being 
students. Moreover, the Miftahul Khoir Islamic Boarding School environment in Bandung City immediately mingles with the outside community, and the schools and colleges in the area around the Pondok as well as students and students not only from among the students, but also from the outside community. Therefore, an anticipatory attitude must always be carried out, and the control of the students must be improved so that the threats that arise can be immediately overcome.

\section{REFERENCES}

Ardhiarta, A. A. (n.d.). Kesantunan Berbahasa Dalam Interaksi Sosial di pondok Pesantren Darul Ulum Jombang: Suatu Kajian Pragmatik. Jurnal Skriptorium, 2(1), 1-15.

Asifudin, A. J. (2016). Manajemen Pendidikan untuk Pondok Pesantren. Manageria: Jurnal Manajemen Pendidikan Islam, 1(November), 355-366.

Dhuhani, E. M. (2018). Manajemen Pondok Pesantren; Studi Pengelolaan Santri Muallaf di Pondok Pesantren $\mathrm{Al}$ Anshar Ambon. Jurnal Fikratuna, 9(1), 54-70.

Gunarwan. (2006). Linguistik Indonesia.

Masyarakat Linguistik Indonesia.

Gunarwan, A. (2002). Pedoman penelitian pemakaian bahasa. Pusat Bahasa, Departemen Pendidikan Nasional.
Habibi, I., \& Supriatno, T. (2020). Charity Punishment in Islamic Boarding School to Improving Santri Discipline. Ną̧bruna: Jurnal Pendidikan Islam, 3(3), 342-354. https://doi.org/10.31538/nzh.v3i3. 767

Hasbi, F., \& Diani, Y. P. (2020). Model Kepemimpinan di Pondok Pesantren. PRODU: Prokurasi Edukasi Jurnal Manajemen Pendidikan Islam, 2(1), 63-78.

Inderasari, E., Achsani, F., \& Masyhuda, H. M. (2019). Strategi Komunikasi Dalam Kesantunan Berbahasa Komunitas Antarsantri Pondok Pesantren Al-Hikmah Sukoharjo. Jurnal Semiotika, 19(1), 57-66.

Ita Herlitasari, Mustolah Maufur, S. I.

(2020). Manajemen Pembinaan Santri Melalui Kegiatan Organisasi Pelajar Pondok Pesantren Modern Al-Umm Aswaja Ciawi Bogor. Jurnal Tadbir Muwabhid, 4(2), 161-182. https://doi.org/10.30997/jtm.v4i2.3 273

Khotimah, K. (2017). Tingkat Kesantunan Berbahasa Dalam Interaksi Antar Santri di pondok Pesantren AtTa'awun Bangkalan Madura (Kajian Pragmatik). Jurnal Inovasi Pendidikan, 1(September), 19-27.

Ma arif, M. A., \& Kartiko, A. (2018).

Fenomenologi Hukuman di 
Pesantren: Analisis Tata Tertib

Santri Pondok Pesantren

Daruttaqwa Gresik. Nadwa, 12(1), 181-196.

https://doi.org/10.21580/nw.2018.

12.1.1862

Muslimin, T. A., \& Kartiko, A. (2020).

Pengaruh Sarana dan Prasarana

Terhadap Mutu Pendidikan di

Madrasah Bertaraf Internasional

Nurul Ummah Pacet Mojokerto.

Munaddhomah: Jurnal Manajemen

Pendidikan Islam, 1(2), 75-87.

https://pasca.jurnalikhac.ac.id/inde

x.php/munaddhomah/article/view/ 30

Natashia, L. (2016). Apa Itu Kesantunan Berbahasa dan Apa Saja Prinsip Untuk. Berbahasa Santun?

Https://Www.Kompasiana.Com/Li onynatashia/Apa-Itu-KesantunanBerbahasa-Dan-Apa-Saja-PrinsipUntuk-Berbahasa-Santun.

Nurmadiansyah. (2016a). Manajemen Pendidikan Pesantren: Suatu Upaya Memajukan Tradisi. Jurnal Manajemen Dakwah, 2(1), 95-115.

Nurmadiansyah, M. T. (2016b). Manajemen

Pendidikan Pesantren: Suatu Upaya Memajukan Tradisi. Jurnal MD, Januari-Ju, 95-115.

Nurmela, S., \& Rifa, A. B. (2016). Manajemen Pondok Pesantren Salafiyah dalam Meningkatkan
Kualitas Santri. Tadbir: Jurnal Manajemen Dakwah, 1(4), 390-406.

Rahardi, R. K., \& Rahardi, R. K. (2005). Pragmatik: Kesantunan imperatif bahasa Indonesia. Erlangga.

Rahardjo, M. D. (1999). Islam dan transformasi sosial-ekonomi. Lembaga Studi Agama dan Filsafat.

Salis, M. R. (2020). Kyai Leadership Style in Developing the Majelis Taklim in Islamic Boarding School. Nidhomul Haq: Jurnal Manajemen Pendidikan Islam, 5(3), 392-410. https://doi.org/10.31538/ndh.v5i3. 842

Shobirin, M. S., \& Roziqin, M. K. (2019). Analisis Kesantunan Berbahasa Santri di Lingkungan Pondok Pesantren Yanabiul Qur, an Jombang: Kajian Pragmatik. UNW AHA Jombang, 26 Oktober, 6671.

Sugiyono. (2015). Metode Penelitian Kuantitatif Kualitatif dan R\&D. Alfabeta.

Supian, S., Rahman, K. A., Daud, S. M., \& Thohirin, N. (2020). Development of Pesantren Teachers In The Perspective of Uswah Nubuwah. Ną̧hruna: Jurnal Pendidikan Islam, 3(3), $\quad$ 371-388. https://doi.org/10.31538/nzh.v3i3. 693

Supratman. (n.d.). Kesantunan Berbahasa Indonesia Santri Dalam Pergaulan 
Nidhomul Haq, Vol 6, Issue 1, 2021

Di Lingkungan Pondok Pesantren

Al-Bayan Makassar. Program

Pascasarjana Universitass Negeri

Makassar.

Tambak, S., Amril, A., \& Sukenti, D. (2021).

Islamic Teacher Development:

Constructing Islamic Professional

Teachers Based on The Khalifah

Concept. Ną̧hruna: Jurnal Pendidikan

Islam, $\quad 4(1), \quad 117-135$.

https://doi.org/10.31538/nzh.v4i1.

1055

Wijaya, Y. L. W. dan H. (2017a). Analisis

Kesantunan Berbahasa Menurut

Leech Pada Tuturan Berbahasa Arab

Guru Pondok Pesantren Ibnul

Qoyyim Putra Yogyakarta. Jurnal Al

Bayan, 9(1), 1-16.

Wijaya, Y. L. W. dan H. (2017b). Analisis

Kesantunan Berbahasa Menurut

Leech Pada Tuturan Berbahasa Arab

Guru Pondok Pesantren Ibnul

Qoyyim Putra Yogyakarta Tahun

Ajaran 2016/2017 (Kajian

Pragmatik). Jurnal Al Bayan, 9(1), 1-

16. 